\title{
Editorial: Occupational pension schemes can prosper again
}

The year 2004 was a bad news year for occupational pension schemes in the UK. Newspapers were again full of the 'pensions crisis', with only the government still in denial. For ministers to admit to a crisis would be to accept that someone must be to blame. And while there is no single cause for the dismantling of Britain's proud pension heritage, government action and inaction have been a major cause of the difficulties. No one can blame the government for the recent dire stock market performance, or the pleasant problem of improving longevity. But the opportunistic tax grab in 1997 and the imposition of pension increases in the 1995 Pensions Act were damaging. The 1995 Act, and all other recent legislation, was well-intentioned, but the government would not heed the warnings that their 'cures' were killing the patient.

Making the same mistake again in 2004 with the new Pensions Act is more than careless. This Act started life as a laudable intention to reduce the regulatory burden for pension scheme sponsors, but was hijacked along the way following some high-profile scheme collapses. The plight of pension scheme members being left with little after insolvencies was distressing, but politicians should know that hard cases lead to bad laws - just think of Robert Maxwell. The 2004 Pensions Act is now solely about security. It is easy for the politicians to crow about the steps taken to make schemes more secure, but disingenuous when the bigger tragedy is that far fewer workers in the UK now get the chance of a decent pension.

$\mathrm{Up}$ and down the land pension scheme doors were closing. Actuaries take pride in the part they have played for more than 50 years in encouraging good British pension schemes, and although busy again in 2004, much of the actuaries' work is now less than satisfying: there is no pleasure in presiding over scheme closures.

\section{The Turner report}

Late in 2004 a light appeared on the horizon. The government too easily sets up enquiries and commissions rather than facing up to hard decisions, but the pensions audience had great hopes for the Pensions Commission headed by Adair Turner. It was soon clear that Turner and his team were completing a serious review, and would be thorough in their approach. We waited in eager anticipation. Would Turner be bold enough to bring state benefit reform into play - even though it was not part of his brief? And if he did would Ministers act? Without exception, the pension bodies have been unanimous in their calls for reform of state pensions as a prerequisite for breathing new life into the private pensions sector. 
Turner issued his report in October 2004 and we were not disappointed! Although we saw only an interim report, it was clear that the Commission would be bold. Their report proved to be the most significant review of pension provision for twenty years. The interim Turner report is light on recommendations. Instead Turner has given us breathing space, not only for us to reassure him that his facts are correct, but also to provide a chance for all concerned to comment on the direction he is taking. Turner also wanted to save his best until after the coming UK general election lest he become a political football. This is understandable, but pensions will be alongside education and health on the election agenda, and it would have been useful to know where our candidates stand as regards the hard pensions decisions that are already overdue.

The Association of Consulting Actuaries (ACA), the largest national grouping of consulting actuaries in Europe, felt the interim report was an extremely thorough description of the current UK pensions system and was well researched (drawing as it did on a wide range of sources, including the ACA's pension trend surveys of larger and smaller companies). The ACA were happy with the financial assumptions used by Turner in his projections.

\section{Stark choices}

Turner challenges us all to face up to four stark options:

1. let pensioners become poorer in comparison with the rest of society;

2. accept that higher tax or National Insurance should be devoted to pension provision;

3. take steps to increase private pensions saving; or

4. raise retirement ages.
All pensions bodies submitted their responses at the end of January and the Commission is now heads-down again preparing the final recommendations due in the autumn. That final report will include the Commission's conclusions on the effectiveness of the existing UK pension system, in particular its private elements, and recommendations for change. It will present the Commission's conclusions on whether there is a need to expand the role of compulsion beyond that which is already implicit in the State Second Pension and the contracting-out options.

\section{The government's role is poverty prevention}

The ACA favours a system whereby the government's role is limited to poverty prevention, allowing individuals to decide what level of pension income in retirement they want, over and above a level sufficient to cover essential basic living costs pard by the state to all pensioners. Additionally, the government should have a responsibility to encourage private saving above the state pension by way of tax incentives and an appropriate regulatory regime that supports (rather than frustrates) that objective.

In a free society, over and above a pension sufficient to cover essential basic living costs, individuals should be able to choose what level of income, broadly. they wish to have in retırement. Some might choose higher levels of consumption during their lifetıme against higher incomes in retirement through extra savings. Provided that by opting for higher consumption levels those exercising the choice do not expect others - both present taxpayers and future generations of taxpayers - to find substantial amounts to raise their incomes in retirement to basic levels, then society should have no objection. 


\section{Better financial education}

It is clear that for individuals to make the 'informed choices' necessary to determine this trade off between current consumption and adequate savings, considerably more investment is required by society in financial education. There should be initratives to make basic financial education part of the national curriculum, so that those leaving school at the age of 16 have the opportunity to better understand and act in matters of personal financial planning. Current levels of education in these areas are

lamentable. There is some

disappointment that, whereas this approach has been talked about for a number of years, very much less progress has been made in reforming the education system to encourage the acquisition of practical day-to-day skills than might reasonably have been expected.

\section{Means testing is only a short-term fix}

It is accepted that the means-tested pensions credit system implemented by the present government was designed to address low incomes for pensioners, many of whom did not have the opportunity in their working lives (many of them women) to save at levels sufficient to provide a decent pension, and who cannot now do this.

It should be stated public policy, however, to phase out this means-testing over a period of years and not, as is the case at present, to embed the regime by offering higher indexation of the benefit, increasing it at a faster rate than the basic pension. Unless this policy changes, as the Commission comments, the numbers in receipt of means-tested pension credits will grow, as will the level of average benefits paid. The disincentive to save into personal plans and group schemes will continue to grow, particularly among those with lower incomes and,

increasingly, will affect those on middle incomes.

\section{Turner's four options}

Responding to the four policy options identified by the Pensions Commission to solve the 'pensions crisis', the ACA favours a mix of higher savings and a higher retirement age and accepts that higher taxes and/or National Insurance contributions (NICs) might also be necessary.

Turner's first option - allowing pensioners to become relatively less wealthy compared with the working population - is unacceptable, although this will happen if the government is indecisive in addressing the hard choices raised by the Commission's report.

The ACA submission to Turner accepts the vast majority of the conclusions contained in the Pensions Commission report and the reasons given for the widespread decline in pensions provision.

\section{The key ACA policy recommendations}

In its response to Turner the ACA has made a series of key recommendations which it believes will encourage new workplace schemes. After all, the schemes whose loss we now mourn were all workplace schemes, and there is no reason why they cannot be re-established.

- The basic state pension and S2P should be consolidated into a higher-level basic state pension. This would be set at a level sufficient to cover essential basic living costs, to be reviewed annually to reflect earnings growth. This level should be 
recommended to the government by an independent body such as the Pensions Commission, to be reviewed on an annual basis to take earnings growth into consideration. It is felt this higher consolidated basic state pension will form the secure underpin upon which many citizens feel it is necessary to build private pensions. There is a broad consensus across political views that this is the correct long-term approach and that this is helpful and essential if citizens are to have confidence that the state will honour such a policy over the longer term.

- The state pension age should be increased. This would help finance a change over a transitional period rising, in steps, to age 70 . Furthermore, there also needs to be an acceptance that the state pension age must be reviewed from time to time by the Pensions Commission to reflect on-going mortality changes and, particularly, increases in healthy life-spans. We believe the current government's policy of offering inducements to delay drawing a state pension are not a sufficient recognition of the changes necessary to address the cost consequences of mortality changes. There is a further benefit in being honest about state retirement ages. More employers and individuals will appreciate the need for realism in setting their own levels of pensions savings.

- The long-term policy must be set now. In the short term, the cost of paying a higher consolidated basic state pension may not be met by a slow increase in the state retirement age. It must also be recognised that pressures on government spending are presently high and that there may be a limited ability to raise etther NICs or general taxes. These problems must not cause the government to go soft on reform or to take the 'muddle through' option referred to in the Commission's report. This route would lead to millions of pensioners in the future facing reductions in their relative position compared to those in employment (and, in all likelihood, the collapse of the present means-tested pension credit due to its rising cost).

\section{- Contracting-out should be} abolished. It is likely that the public would find a pension regime whereby private pensions are built on top of a consolidated state pension much easier to comprehend. The ACA judges simplicity to be highly important in securing support for changes.

Additionally and importantly, the failure to provide attractive contracting-out terms (despite the strong representations made by many bodies in the pensions industry at the last review in 2002) has undermined the original intent that rebates should encourage much greater private provision while reducing claims on the state's resources.

It is accepted that all contracted-out schemes would lose contracted-out rebates (which cost the taxpayer f.10.5bn per year) from a certain date and thereafter pay contracted-in NICs. The new NIC rates should be set at roughly the present contracted-out rate plus an across the board supplement to meet the anticipated long-term extra cost of paying the consolidated basic state pension.

\section{- An incentive for employers should} be restored. When contracting-out was first established, the National Insurance rebate terms did provide a positive financial incentive to employers to set up private pension schemes, and many did so. Many good schemes started in the 1970s and 1980s, taking advantage of this subsidy and so it is clear that it works. Most 
actuaries and employers would agree that the present terms offer no such encouragement.

The state should provide an incentive (probably by way of a reduction in employer NIC rates). This incentive should be targeted and encourage the development of second-tier private pensions, where employers continue to or decide to sponsor schemes that meet a certain standard (for example, a minimum of 5-10 per cent employer contribution matched by a 5 per cent employee contribution).

- Tax relief remains crucial. The state's encouragement of private pension provision above the state minimum should continue by way of tax relief, with long-term saving attracting a higher rate of relief than short-term savings products.

- Employers must be free to amend schemes. When employers first established defined benefit (DB) schemes, the huge cost of additional regulations and legislation enacted over the last 20 years was not anticipated. These enforced changes, such as LPI guarantees, have added major costs doubling in some cases the cost of funding a scheme, never mind the additional costs of administration. Pension schemes lost their 'safety valve': in the past schemes could delay or reduce pension increases when times were difficult (and this may still be done in the Netherlands, it is perhaps no coincidence that this is the only country in Europe where DB schemes still thrive). Employers who thought that they had agreed to subsidise employee contributions on a two-to-one ratio (typically employer 10 per cent and employee 5 per cent) found that the level of their subsidy had grown to four or even five times. Rather than have to close schemes to new members and future accruals, the government should allow genuine pension simplification. This should include the right for employers to change scheme rules retrospectively to reduce unexpected rises in costs, including raising the normal retirement age (albeit that we recognise that most scheme rules would presently not permit this change and the Human Rights Act might be used to oppose such changes). What is intended here is not that there should be a reduction in members' past service entitlement, but rather that the value of past service benefits should not automatically increase due to future improvements in longevity. Increasing the normal retirement age is just one possible way of doing this. Blind protection of accrued rights under s. 67 of the 1995 Act has back-fired and government should be big enough to recognise this. Schemes would regain their safety valve. After all, retirement ages under defined contribution (DC) schemes will rise simply because satisfactory benefits will not be affordable at 65 .

\section{Compulsion is not the answer}

The scheme that an employer wants to set up will always be better than a scheme he has to establish. Many believe the next Pensions Commission report may be tempted to recommend the introduction of compulsory private pension contributions. If the ACA proposals were implemented, compulsory minimum private pension contributions would be unnecessary. Compulsory contributions would have a 'levelling-down' affect on private pension contributions, particularly from employers. The Commission report notes how this has already occurred as employers have moved from DB to DC schemes. If, however, these views are 
ignored and, it is apprecrated, there are superficial attractions for the government in going for compulsion, great care is needed. As a solution to the 'pensions crisis' compulsion effectively increases 'private taxes' and requires less robust decision making by government.

Without state reforms, more of the costs of providing basic level pension provision will pass to the private sector.

To place this cost at proper levels on smaller firms would be highly dangerous in raising their costs at a time when in many sectors (save public services) prices are being reduced to maintain market share, particularly those open to world markets. If compulsory private pension contributions are to be introduced they would best be phased in, as in Australia, over a number of years, ideally against a back-cloth of generally reducing levels of taxes on both companies and individuals. However, lower taxes seems unlikely to be enforced in the UK over the next few years, unless there is some major change in government expenditure policies.

Alternatively, a move towards greater compulsion would need to be accompanied by general encouragement during the phasing-in period of 'total remuneration' packages, where pension contributions are seen as part of the overall benefits package that all employers should offer. During the phasing-in period, employers would be encouraged to introduce and/or increase pension contributions as part of annual remuneration reviews (as opposed to straight wage/salary increases).

Consideration might also be given to offenng restricted tax relief to firms that do not pay employer contributions above a certain level.

\section{Compulsion at low contribution rates is dangerous}

There would also be a need for honesty about the levels of pension contributions that are needed. If there were no major changes to the state system, the government would need to legislate so that, over the transition period, minimum employer and employee contributions rose up to, say, 5 per cent +5 per cent of earnings for younger workers, but perhaps 7.5 per cent +7.5 per cent for those aged 40 or more, and so on. Given current pension credit policies, legislating for minimum contributions at, say, 3 per cent +3 per cent could be dangerously close to mis-sellnng aided and abetted by government.

Minimum contributions would need to be directed into open employer sponsored arrangements where schemes are presently offered, due to lower costs, they would tend to offer higher returns. Clearly, where existing employer and employee contributions equal or exceed the minima, no changes in arrangements, governance or investment approaches would be required.

Where employers do not offer a scheme at present or there is an unused stakeholder, the employer would be required to open a new employer's scheme (or activate the existing stakeholder). In such circumstances, the scheme would need to offer a default investment strategy and lifestyle strategies. Ideally, administration costs would be fixed at no more than stakeholder costs.

In both cases, where employees desired to opt-out they should lose the employer's contribution, and be required to pay a higher (doubled) minimum contribution into a personal pension of their choice. Under no circumstances where employers offer a scheme should they be required to contribute to a 'mess' of personal arrangements as this would lead to unreasonable administrative burdens. 


\section{A 'citizen's' pension?}

In reforming the basic state pension, it is recognised that the growing support for a 'Citizens' pension', unrelated to NICs, has considerable attractions in terms of simplicity, and the potential to reduce administration costs. It would also help achieve one of the Pension Commission's key objectives - raising the comparative level of women's pensions, particularly for those with less lengthy NI contribution records. There are, however, a number of issues that need to be considered before full-hearted support is given to the proposal. These include issues such as 'who is a UK citizen?' In an increasingly open EU labour market when would it be fair to grant a full UK basic state pension to those who might have worked or lived for only a short period in the UK? The implications of losing the contributory principle also need to be carefully considered.

\section{There is a role for defined benefits}

The recent shift from DB to DC provision has been monitored by the ACA since 1996 when in our report The Changing Face of UK Occupational Pensions we noted 'levels of pension contributions by companies are significantly lower into defined contribution arrangements compared to defined benefit schemes. There is a danger that the degree of funding in many defined contribution arrangements is likely to be insufficient to provide the levels of pensions needed or expected by tomorrow's pensioners.'

\section{The Commission's conclusions are very similar}

It needs to be pointed out, however, that while a small minority of $\mathrm{DB}$ schemes have had to be wound up with sizeable deficits, very many more even where they may be closed to new members - are receiving sizeable one-off contributions from employer sponsors or are receiving much higher levels of regular employer contributions. While to a degree this may be enforced action (the additional contributions are needed to meet the higher than expected cost of the benefits offered), it shows many employers are still committed to their pension arrangements and are prepared to contribute at levels that will help deliver 'good' pensions.

It can be expected that many employers remain committed to pensions and will take on investment rnsk within a DB scheme (even if not final salary arrangement). However, far fewer are now prepared to take on mortality risk, because they are uncertain about just how quickly average life spans will improve over the period ahead. This is very understandable in an environment where companies are increasingly required to evaluate, manage and limit risks that could undermine shareholder value.

There may be a change in the political climate as pensions emerge as one of the main political issues of the day (which they have now become). The general interest may cause more employers - particularly smaller ones to consider the package they offer and what it is likely to deliver to their staff on retirement. We believe that if there is some wider public pressure and a broader understanding that, say, a 15 per cent of earnings ( 10 per cent employer +5 per cent employee) pension contribution should be the 'norm' then this might influence employers to gradually improve their contributions. This outcome would be more likely if the state and private pension system became clearer in the way we propose above. 


\section{Campaign to raise pension savings}

The ACA believes that there should be a concerted campaign from the government, business and labour to encourage employers to offer pension schemes, and employees and individuals to save more, including pension saving. While there may be macro-economic downsides to raising the level of pension savings in the short term, we believe over the longer term that a much wider level of pension savings across income groups is beneficial to society as a whole and to individuals in terms of the freedoms this offers. Governments should in particular try to harness employers as advocates for pension savings given the advantages that work-based group arrangements can offer in terms of cost and administration.

In a labour market where high skills and dependable service are in demand, more employers can be persuaded of the value of providing good pensions to meet the aspirations of their employees. This is always provided that running a scheme does not add an unreasonable administrative and regulatory burden (which many employers think they presently do) or unreasonably add risks to the running of their business (again, which many employers think they presently do).

\section{The Commission should become permanent}

A final thought. We know that politicians duck the difficult decisions. Privately politicians well know that higher retirement ages are inevitable, but dare not face their electors with that. If only Turner's commission could become permanent, thereby forcing governments to face the knotty problems as they arise. Pensions are too important to be left to politicians. They have let us down.

Adrian Waddingham Partner, Barnett Waddingham Chairman, Association of Consulting Actuaries 